\title{
Uji Kontaminasi Bakteri Pada Spons Pencuci Piring Ibu Rumah Tangga Berdasarkan Lama Penggunaan
}

\author{
Arista Suci Andini ${ }^{1}$, Putri Sari Uswatun Hasanah ${ }^{2}$, Syuhriatin ${ }^{3}$ \\ ${ }^{123}$ Program Studi Biologi, Fakultas MIPA Universitas Islam Al-Azhar, Indonesia
}

\begin{tabular}{l} 
Article Info \\
\hline Article history: \\
Received Jun $17^{\text {th }}, 2021$ \\
Revised Aug $26^{\text {th }}, 2021$ \\
Accepted Aug $26^{\text {th }}, 2021$ \\
\hline
\end{tabular}

Keyword:

Bacteria, Contamination, Dish-washing sponges

\begin{abstract}
Dish-washing sponges are ideal places for microorganisms such as harmful bacteria and other pathogens such as e-coli, Staphylococcus aureus, and salmonella. Sponge is generally used in the kitchen for the purposes of washing household appliances such as plates, cups, and others. This study aims to identify bacteria found in dishwashing sponges used by housewives. Identification is done by inoculation method of dishwashing sponge water immersion where this method serves to determine the species of bacterial contaminants that grow in the sample. This study uses 3 respondent populations with different usage periods between 2 weeks, 4 weeks and 6 weeks. The results showed there was bacterial contamination in the span of 6 weeks. The identification results show that the growing microbes are E-coli which is a pathogenic bacterium. Based on the results of the study it can be seen that sponge samples with usage of more than 4 weeks showed positive results of E. coli bacterial contamination so that it can be concluded that the safe time span in the use of sponges to be replaced is 4 weeks.
\end{abstract}

\begin{abstract}
ABSTRAK
Spons pencuci piring merupakan tempat yang ideal untuk mikroorganisme seperti bakteri berbahaya dan patogen lainnya seperti e-coli, Staphylococcus aureus, dan salmonela. Spons umumnya digunakan di dapur untuk keperluan mencuci peralatan rumah tangga seperti piring, gelas, dan lainnya. Penelitian ini bertujuan untuk mengidentifikasi bakteri yang terdapat pada spons pencuci piring yang digunakan oleh ibu rumah tangga. Identifikasi dilakukan dengan metode inokulasi rendaman air spons pencuci piring dimana metode ini berfungsi untuk mengetahui spesies bakteri kontaminan yang tumbuh pada sampel. Penelitian ini menggunakan 3 populasi responden yang dengan rentang waktu penggunaan yang berbeda antara 2 minggu, 4 minggu, dan 6 minggu. Hasil penelitian menunjukkan terdapat kontaminasi bakteri pada rentang waktu 6 minggu. Hasil identifikasi menunjukkan mikroba yang tumbuh adalah E-coli yang merupakan bakteri pathogen. Berdasarkan hasil penelitian dapat diketahui bahwa sampel spons dengan pemakaian lebih dari 4 minggu menunjukan hasil Positif kontaminasi bakteri E-coli sehinggadapat disimpulkan rentang waktu yang aman dalam penggunaan spons untuk diganti adalah adalah 4 minggu.
\end{abstract}

Kata Kunci : bakteri, kontaminasi, Spons pencuci 
Jurnal Analis Medika Biosains (JAMBS)

Vol.8, No.2, September 2021, pp. 130 - 134

ISSN: 2656-2456 (Online)

ISSN: 2356-4075 (Print)

Pendahuluan

Spons dapur menawarkan tempat yang ideal untuk mikroorganisme seperti, bakteri berbahaya dan patogen lainnya. Bakteri patogen antara lain Escherichia coli, Salmonella, Klebsiella pneumoniae, dan Enterobacter cloacae. Spons biasanya digunakan di dapur untuk keperluan mencuci peralatan rumah tangga seperti piring, gelas dan lainnya (Ikawa dan Rossen,1999). Spons digunakan untuk membersihkan permukaan peralatan rumah tangga, jika spongs yang digunakan dalam waktu yang cukup lama akan lebih berpotensi tumbuhnya bermacam-macam mikroorganisme. Sulanjari (2010) menyatakan sponge pencuci piring biasanya terbuat dari busa yang tidak dapat teruraikan. Kebiasaan meniggalkan spons pencuci piring di dalam air sabun kurang tepat karena bakteri dapat berkembang di dalam air. Air sabun yang bersentuhan dengan busa yang telah digunakan untuk mencuci yang berakibat sponge akan dipenuhi oleh bakteri. Penggunaan sponge dalam keadaan tersebut untuk mencuci piring akan menyebabkan piring menjadi sarang bakteri.

Peneliti asal Arizona, Amerika Serikat, mengumpulkan 1.000 lap dapur dan spons cuci, mereka menemukan bahwa 10 persen di antara benda-benda itu mengandung Salmonella.Setiap inchi persegi permukaan lap dan spons itu memiliki sekitar 134.630 bakteri, 456 kali lebih banyak daripada jumlah bakteri di dudukan toilet. Lap dapur dan spons menjadi tempat E. coli dan bakteri fecal lain yang paling banyak ditemukan pada skala rumah tangga. Hal ini disebabkan kedua benda tersebut paling jarang diganti. Beberapa studi menunjukkan bahwa berbagai bakteri, termasuk Escherichia coli, Staphylococcus aureus dan Salmonella spp., bertahan hidup di tangan, spons / kain, peralatan dan mata uang selama berjam-jam atau hari setelah kontak awal dengan mikroorganisme (Kusumaningrum et al., 2002).

Seringkali kita tidak terlalu memperhatikan kebersihan spon cuci piring bahkan ada yang sampai berbulanbulan tidak diganti dengan yang baru, Hal ini dipastikan akan mempercepat pertumbuhan mikroba. Oleh karena itu perlu dilakukan uji untuk mengetahui berapa rentang waktu yang aman dalam menggunakan spons pencuci piring.

\section{Metode Penelitian}

Jenis penelitian ini adalah bersifat deskriptif analitik yaitu untuk memberikan gambaran tentang realitas pada objek yang diteliti secara obyektif (Notoatmodjo, 2005). Penelitian ini akan dilakukan di Laboratorium Kesehatan Pengujian Kalibrasi dan Penunjang Medis Provinsi Nusa Tenggara Barat. Penelitian ini dilaksanakan pada tanggal 12 juli 2019 sampai dengan Oktober 2019. Sampel yang digunakan adalah sampel di 3 titik rumah yang memiliki spons pencuci yang telah ditentukan waktu pemakaiannya.

Setelah 24 jam diamati untuk melihat perubahan kekeruhan yang terjadi untuk dilakukan proses lebih lanjut, jika terjadi perubahan warna menjadi keruh dilanjutkan ke proses penanaman pada media EMB, BAP, dan XLD. Hasil penanaman pada media padat dibandingkan dengan kontrol bakteri yang digunakan sebagai acuannya seperti : e-colli, salmonella, dan staphylococcus. Apabila ditemukan koloni yang menyerupai kontrol maka dilakukan uji penegas biokima dan dilakukan pemeriksaan dibawah mikroskopis menggunakan cat gram. Hasil identifikasi jenis bakteri yang ada pada spons pencuci piring disajikan dalam bentuk tabel dan gambar kemudian data tersebut dianalisis secara deskriptif.

Journal homepage: http://jambs.poltekkes-mataram.ac.id/index.php/home/index 
Jurnal Analis Medika Biosains (JAMBS)

Vol.8, No.2, September 2021, pp. 130 - 134

ISSN: 2656-2456 (Online)

ISSN: 2356-4075 (Print)

\section{Hasil Penelitian dan Pembahasan}

Berdasarkan penelitian yang telah dilakukan untuk mengidentifikasi bakteri pada spons pencuci piring dengan rentang waktu penggunaan 2 minggu (A), 4 minggu (B) dan 6 minggu (C) yang digunakan oleh responden. Didapatkan hasil seperti yang ditampilkan pada tabel 1.

Tabel 1. Identifikasi bakteri pada spons pencuci piring

\begin{tabular}{|c|c|c|c|c|c|}
\hline \multirow[b]{2}{*}{ No. } & \multirow[b]{2}{*}{ Sampel } & \multicolumn{4}{|c|}{ Hasil Identifikasi Bakteri } \\
\hline & & Salmonella & $\begin{array}{c}\text { Staphylococcus } \\
\text { aureus }\end{array}$ & E.coli & Keterangan \\
\hline 1. & 2 minggu $(\mathrm{A})$ & Negatif & Negatif & Negatif & Tidak ada pertumbuhan koloni \\
\hline 2. & 4 minggu (B) & Negatif & Negatif & Negatif & Tidak ada pertumbuhan koloni \\
\hline 3. & 6 minggu $(C)$ & Negatif & Negatif & Positif & $\begin{array}{l}\text { - Tumbuh koloni } \\
\text { - Koloni sedang sampai besar } \\
\text { - Smooth } \\
\text { - Berwarna hijau metallic } \\
\text { - Hemolysis (zona bening } \\
\text { disekeliling koloni }\end{array}$ \\
\hline
\end{tabular}

Sumber : Data primer 2019

Sampel ditanam pada media selektif/diferensial dan diinkubasi selama 24 jam dengan suhu $35^{\circ} \mathrm{C}$ untuk diamati koloni bakteri yang tumbuh untuk dapat mendeteksi dan memastikan adanya kontaminasi bakteri. Berdasarkan hasil pengamatan koloni pada media diferensial EMB didapatkan koloni menyerupai ciri dari E. coli seperti yang teramati pada kontrol positif. Gambaran perbandingan sampel positif bakteri dengan kontrol positif dapat dilihat pada gambar 1.

Kontrol

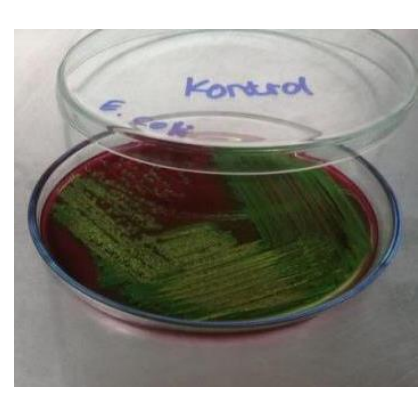

Perlakuan

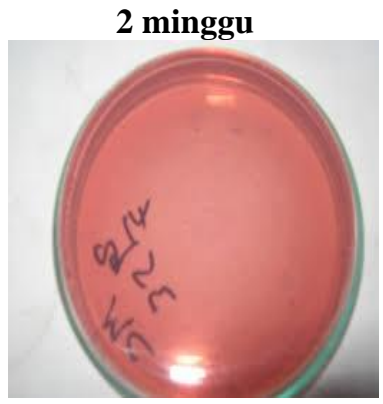

4 minggu

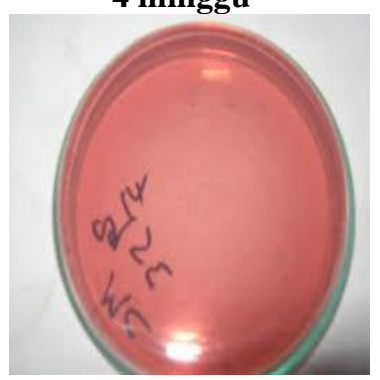

6 minggu

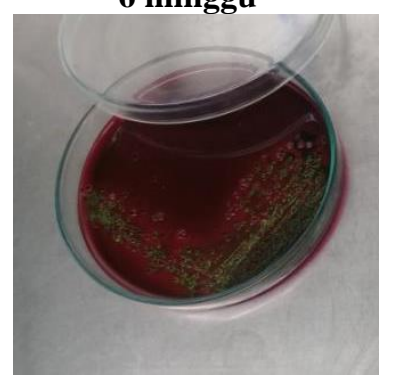

Gambar 1. Inokulasi bakteri kontaminasi pada media padat

Sumber : Data primer 2019

Penelitian ini sejalan dengan penelitian Bobihu (2012) yang melakukan pemeriksaan identifikasi dan angka kuman pada peralatan makan di rumah makan kompleks pasar sentral kota Gorontalo, berdasarkan hasil observasi bahwa sebanyak 5 kantin (D, E, G, M, N) yang menyimpan peralatan makan dalam keadaan tidak kering sehingga menyebabkan peralatan tersebut ditempeli debu dan kotoran lainnya. Selain itu, pada penelitian ini terdapat 12 rumah makan yang cara penyimpanannya tidak memenuhi syarat ketentuan penyimpanan peralatan sehingga memungkinkan terjadi pengotoran atau kontaminasi pada alat makan. 
Jurnal Analis Medika Biosains (JAMBS)

Vol.8, No.2, September 2021, pp. 130 - 134

ISSN: 2656-2456 (Online)

ISSN: 2356-4075 (Print)

Hasil identifikasi sampel yang menunjukan hasil positif bakteri yang ditandai dengan adanya pertumbuhan bakteri pada media padat kemudian diuji lanjut dengan uji penegas seperti yang ditampilkan pada tabel 2.

Tabel 2 Uji Biokimia bakteri pada spons pencuci piring

\begin{tabular}{cccccccccc}
\hline \multirow{2}{*}{$\begin{array}{c}\text { No. } \\
\text { Sampel }\end{array}$} & \multicolumn{4}{c}{ Uji biokimia } & \multicolumn{4}{c}{ Uji gula-gula } & Keterangan \\
\cline { 2 - 7 } & Indol & MR & $\begin{array}{l}\text { Cimon } \\
\text { Citrat }\end{array}$ & Urea & TSIA & Glukosa & Laktosa & Sukrosa & \\
\hline 6 minggu & + & + & - & - & A/A & + & + & + & E. coli
\end{tabular}

Sumber : Data primer 2019

Pemeriksaan rendaman spons ini dilakukan untuk mengetahui rentang waktu penggunaan spons yang layak oleh masyarakat. Berdasarkan hasil penelitian yang telah dilakukan maka dapat disimpulkan bahwa rentang waktu yang layak dalam penggunaan spons adalah maksimal 4 minggu, karena pada pengamatan didapatkan bahwa spons setelah penggunaan 6 minggu terdeteksi telah mengalami kontaminasi bakteri. Bakteri kontaminan yang ditemukan pada spons dengan penggunaan 6 minggu adalah E. coli.

Penelitian lain terkait deteksi kontaminan spons pencuci piring menunjukkan bahwa pada spons pencuci piring telah tumbuh empat jenis bakteri yang berbeda, dimana salah satunya adalah E. coli. Bakteri E. coli merupakan enterobakter, beberapa galur $E$. coli merupakan bakteri pathogen yang dapat menyebabkan penyakit diare. (Suharto, 2001). Penelitian yang dilakukan oleh Sulanjari (2010) menyatakan dapur merupakan tempat dengan banyak mikroba dan bakteri aktif terbesar di rumah dibandingkan toilet. Studi juga menunjukkan kuman paling banyak di seluruh rumah terletak di saluran pembuangan washtafel dapur. Oleh karena itu, spons dapur juga termasuk barang yang menyimpan banyak bakteri jahat.

Spons cuci piring bertindak penyebar bakteri di dapur sekaligus menyebabkan kontaminasi silang tangan dan makanan yang dapat membuat seseorang sakit. Spons cuci piring menyimpan semua jenis bakteri, salah satunya $e$. coli yang berbahaya bagi seseorang dengan kekebalan tubuh lemah. Barang itu pula yang menjadi tempat terbaik berkembangnya bakteri jahat jika tak pernah dibersihkan dengan baik atau diganti (Sulanjari. 2010). Escherichia coli merupakan bakteri komensal yang hidup di mikroflora usus di berbagai jenis binatang dan manusia, dan dapat 11 menyebabkan berbagai penyakit pada manusia, mamalia dan burung (Hussain, 2015). Mikroorganisme ini terdapat di feses, atau kotoran, yang penyebarannya melalui fekaloral. Makanan dan air yang terkontaminasi adalah cara yang paling umum untuk terkena E.coli. Kebanyakan E.coli tidak menyebabkan penyakit tetapi bakteri E.coli dapat menimbulkan penyakit jika jumlah koloni terlalu banyak, E.coli hidup di luar habitatnya atau keadaan manusia sebagai pejamu yang lemah karena suatu kondisi seperti mengalami penyakit imunosupresan. Manifestasi E.coli pada manusia bergantung dari tempat infeksi tarjadi, oleh sebab itu patogenesis E.coli dibedakan berdasarkan letak organnya yaitu menjadi infeksi ekstraintestinal dan intraintestinal (Jawetz et al., 2013).

Benda yang digunakan untuk mencuci peralatan dapur pun perlu diperhatikan. Salah satunya adalah spons cuci piring yang kerap diabaikan dan diganti jika sudah sudah rusak dan tidak dapat digunakan

Journal homepage: http://jambs.poltekkes-mataram.ac.id/index.php/home/index 
Jurnal Analis Medika Biosains (JAMBS)

Vol.8, No.2, September 2021, pp. 130 - 134

ISSN: 2656-2456 (Online)

ISSN: 2356-4075 (Print)

lagi. Benda tersebut menyimpan banyak bakteri dan kuman yang bisa menggangu kesehatan tubuh manusia. Peralatan makan yang higienis penting untuk mencegah pencemaran dan menjaga keamanan makanan. Semua peralatan yang kontak dengan makanan harus bebas dari bakteri dan mikroba patogen lainnya. Untuk mencegah kontaminasi pada makanan maka semua peralatan harus bersihkan secara rutin (Depkes RI, 2011).

\section{Kesimpulan}

Berdasarkan penelitian diketahui bahwa sampel spons dengan pemakaian lebih dari 4 minggu menunjukan hasil Positif kontaminasi bakteri E. coli sehingga disimpulkan bahwa rentang waktu yang aman dalam penggunaan spons untuk diganti adalah adalah 4 minggu.

\section{Daftar Pustaka}

Bobihu, Febriyani. Studi Sanitasi Dan Pemeriksaan Angka Kuman PadaUsapan Peralatan Makan Di Rumah Makan Kompleks Pasar Sentral Kota Gorontalo Tahun 2012. Jurnal, Jurusan Kesehatan Masyarakat FakultasIlmu-ilmu Kesehatan dan Keolahragaan, Universitas Negeri Gorontalo 2012.

Depkes RI. Keputusan Mentri Kesehatan RI No.715/Menkes/SK/V/2003 Tentang Persyaratan Higyene Sanitasi Jasaboga: Jakarta. 2011.

Hussain T, Chang H.Y, Veenstra C.M, Pollack C.E. Fragmentation in specialist care and stage III colon cancer. Cancer Cythopathology. 2015: 121(18) :3316-3324.

Ikawa, J. Rossen, J. ReducingBacteria in Household Sponges.Journal of Environmental Health 1999: 18-22.

Jawetz, M. \& Adelberg. Mikrobiologi Kedokteran, Edisi 23, diterjemahkan oleh Mudihargi, E., Kuntamah, Wasito, E. B., Mertaningsih, N. M., Huriwati, H. Dkk, Penerbit Buku Kedokteran ECG, Jakarta. 2005.

Kusumaningrum H.D., Riboldi G.,Hazeleger W.C, Beumer R.R. Survival of Foodborne Pathogens onStainless Steel Surfaces and CrossContamination to Foods.International Journal of Food Microbiology. 2002: 5: 227-236.

Notoatmodjo S. Metodologi Penelitian Kesehatan. Rineka Cipta, Jakarta. 2005.

Rini, Sri Dwiari,dkk. Teknologi Pangan Jilid 1. Jakarta : Direktorat Pembinaan Sekolah Menengah Kejuruan, Direktorat Jenderal Manajemen Pendidikan Dasar dan Menengah, Departemen Pendidikan Nasional. 2008.

Suharto A.R.. Microbial community analysis of Indonesian hot-springs. FEMS Microbiol.Lett. 2001 :200(1): 1039.

Sulanjari. Sabut Kelapa Pengganti Spons. FMIPA : UNY Press. 2010.

Journal homepage: http://jambs.poltekkes-mataram.ac.id/index.php/home/index 